\begin{tabular}{|l|l|l||}
\hline \multicolumn{2}{|c|}{ PublisherInfo } \\
\hline \hline PublisherName & $:$ & Palgrave Macmillan UK \\
\hline \hline PublisherLocation & $:$ & London \\
\hline \hline PublisherImprintName & $:$ & Palgrave Macmillan \\
\hline
\end{tabular}

\title{
Measuring societal wellbeing
}

\begin{tabular}{||l|l|l||}
\hline \multicolumn{2}{|c||}{ ArticleInfo } \\
\hline \hline ArticleDOI & $:$ & 10.1057 /palgrave.elmr.1410157 \\
\hline \hline ArticleCategory & $:$ & Feature \\
\hline \hline ArticleFirstPage & $:$ & 46 \\
\hline \hline ArticleLastPage & $:$ & 52 \\
\hline \hline & $:$ & $\begin{array}{l}\text { RegistrationDate }: 2007-10-19 \\
\text { OnlineDate } \quad: 2007-10-19\end{array}$ \\
ArticleHistory & $:$ & Crown copyright2007 \\
\hline \hline ArticleCopyright &
\end{tabular}




\section{Considers what societal wellbeing is, and the main approaches emerging for how it should be measured.}

This article provides an overview of measuring societal wellbeing, also called quality of life or social welfare. GDP and the National Accounts measure economic wellbeing according to an internationally agreed system, but they are increasingly seen as measuring only part of societal wellbeing. The article considers what societal wellbeing is and the main approaches that are emerging for how it should be measured. Some examples are given to show how government around the UK is measuring societal wellbeing. The Organisation for Economic Co-operation and Development and other international organisations are, through the 2007 Istanbul Declaration, promoting debate about what progress means and how a shared view of societal wellbeing can be produced, based on highquality statistics. This article is a contribution to that debate, and is aimed primarily at learning more about the needs for information on wellbeing and progress, and how it would be used. This will help the Office for National Statistics (ONS) develop its analysis programme addressing the priorities of children, ageing, public sector productivity and societal welfare, which is likely to draw initially on existing indicators and may also build on developments in 'satellite' accounts that extend the coverage and scope of the National Accounts.

Misc

The Full Text of this article can be found on the National Statistics website (http://www.statistics.gov.uk/elmr/10_07/downloads/elmr_oct07_allin.pdf). 